\title{
SEM differences in sporophyte micromorphology of Plagiothecium nemorale and P. longisetum (Plagiotheciaceae, Bryophyta)
}

\author{
Grzegorz J. Wolski¹, Magdalena Bihun², Bożenna Białecka², Agnieszka Rewicz ${ }^{1}$ \\ ${ }^{1}$ Department of Geobotany and Plant Ecology, Faculty of Biology and Environmental Protection, University of Lodz, \\ ul. Banacha 12/16, 90-237 Lodz, Poland. \\ ${ }^{2}$ Molecular Biology and Biotechnology Center, Environmental Research Laboratory, University of Szczecin, \\ Małkocin 37, 73-110 Stargard, Poland. \\ *corresponding author: grzegorz.wolski@biol.uni.lodz.pl
}

\begin{abstract}
Plagiothecium nemorale sensu lato is described as a variable Eurasian taxon. Recent studies indicate that this variability is reflected in both qualitative and quantitative features of its gametophyte and its genetic variation. This taxon comprises at least two separate species: $P$. nemorale (Mitt.) A. Jaeger and P. longisetum Lindb. The present paper examines whether the gametophyte variability of these species is reflected in the micromorphological variation of the sporophyte. The analysis revealed that the seta of $P$. nemorale is shorter than that of $P$. longisetum. In addition, regarding the exostome teeth, the lower portion of the outer surface is characterised by loosely-arranged, moniliform cristae in $P$. nemorale, with conical papillae on the upper side; however, in $P$. longisetum it possesses tightly arranged, epapillose cristae, with clearly flattened papillae on the upper side. In addition, the inner surface is more gently papillose in P. nemorale than in the latter. These findings not only describe hitherto unknown features of the sporophyte of these species, but also justify the resurrection of $P$. longisetus as separate from $P$. nemorale.
\end{abstract}

Keywords: Scanning Electron Microscope, sporophyte morphology, taxonomy, Plagiothecium

\section{INTRODUCTION}

As most species of the genus Plagiothecium Schimp. are sterile when collected (Greene, 1957), their taxonomic features tend to concern the morphological characteristics of their vegetative organs, particularly the qualitative features of the stem leaves (Wolski, 2018). Nevertheless, although previous works have focused mainly on the characteristics of the gametophyte, some also provide information on the sporophytes of these species (Lindberg, 1872; Jedlička, 1948, 1950; Nyholm, 1965; Ireland, 1969; Iwatsuki, 1970; Buck \& Ireland, 1989; Noguchi, 1994; Ochyra et al., 2008). However, these data refer only to features that are observable with the use of a light microscope. Only Ireland (1987, 2001) and Ignatov et al. (1996) have described the species of this genus using a Scanning Electron Microscope (SEM). Even so, their studies are fragmentary, referring only to a few selected species and sporophytic structures of these taxa.

One species belonging to the genus Plagiothecium is $P$. nemorale (Mitt.) A. Jaeger, which was described by Mitten (1859) as Stereodon nemoralis Mitt. Over the past 50 years, studies have found that $P$. nemorale was a very variable species, which has resulted in significant taxo- nomic problems (Greene, 1957; Nyholm, 1965; Ireland, 1969; Iwatsuki, 1970; Lewinsky, 1974); however, the causes of this variation were not identified. Eventually, a detailed qualitative and quantitative analysis of the intraspecific variability of the gametophyte of $P$. nemorale sensu lato distinguished at least two groups of specimens. The most important features supporting this division was found to be the length and width of the cells from the upper, middle, and lower parts of the stem leaves. This confirmed the hypothesis that $P$. nemorale had previously been too broadly described, and that it should be considered a complex (Wolski, 2017, 2018). These observations were later confirmed by further taxonomic and molecular research (Wolski \& Nowicka-Krawczyk, 2020), which found that two groups of specimens distinguished by Wolski $(2017,2018)$ are in fact two separate species: $P$. nemorale sensu stricto and $P$. longisetum Lindb.

Unfortunately, there remains a lack of detailed data on the sporophyte micromorphology of $P$. nemorale and $P$. longisetum. The present study was performed to determine whether the gametophyte variability demonstrated by these species is reflected in the micromorphology of 
the sporophyte.

\section{MATERIALS AND METHODS}

Sporophytes were separated into two groups depending on the qualitative and quantitative features of the gametophyte. The material was obtained from two separate species proposed by Wolski and Nowicka-Krawczyk (2020) - P. nemorale sensu stricto and $P$. longisetum. Specimens with symmetrical leaves, a denticulate leaf apex, as well as hexagonal and narrowly hexagonal leaf cells no longer than $100 \mu \mathrm{m}$ in the central part of the leaf were considered $P$. nemorale sensu stricto. Material with asymmetrical leaves, an entire leaf apex, and elongated hexagonal leaf cells longer than $100 \mu \mathrm{m}$ but not exceeding 150 $\mu \mathrm{m}$ in the central part of the leaf was classified as P. longisetum (Wolski, 2017, 2018; Wolski \& Nowicka-Krawczyk, 2020).

The examined sporophytes were collected from 50 specimens deposited in nine herbaria (BIL, $\mathrm{BM}, \mathrm{C}, \mathrm{E}, \mathrm{H}, \mathrm{LOD}, \mathrm{NY}, \mathrm{POZG}, \mathrm{S})$. In good condition and mature sporophytes were gently removed under a binocular microscope from homogeneous turf. The fragments of sporophytes were mounted onto aluminium stubs with double-sided adhesive tape and directly coated with a layer of gold in Quorum Sputter Coater SC7620. The coated sporophytes were observed, and relevant parts were photographed under a Carl Zeiss EVO LS 10 scanning electron microscope (15 kV accelerating voltage was used). Qualitative and quantitative analysis was performed of selected characteristics of the sporophyte samples: the setae (surface, color and length), capsules (orientation, shape, color, length, width), exothecial cells (shape, length, width), opercula (shape, length), exostome and endostome teeth (shape, color, length, width), cilia (length, surface).

\section{Specimens examined}

Plagiothecium nemorale (Mitt.) A. Jaeger, Ber. S. Gall. Naturw. Ges. 1876-1877: 451 (1878) $\equiv$ Stereodon nemoralis Mitt., Journ. Linn. Soc. Bot. Suppl. 1: 104 $(1859) \equiv P$. silvaticum var. nemorale (Mitt.) Paris, Index Bryol.: 967 (1898). Type citation: Hab. In Himalayae orient. reg. temp., Sikkim, in monte Tonglo (ad radicem filicis cujusdam), J. D. Hooker ! Lectotype: "Herb. Ind Or Hook. Fil. \& Thomson Stereodon nemorale m. Hab. Sikkim, Tonglo Regio temp. Alt. - J. D. H." - BM 1030713!: isolectotype: NY 913349!
AUSTRIA, Salzburg, am Dürrenberg bei Hallein, 26 Jun. 1869, L. Berroyer, S B281704. CHINA, Liaoning Prov., Kuandian County, Bai-shi-la-ji National Natural Reserve, trail from fire tower to Xiang-shui-gou at Hu-li Mt., $40^{\circ} 50 ’ \mathrm{~N}, 124^{\circ} 52^{\prime} \mathrm{E}$, alt. 900-1000 m, moist hardwood forest with numerous granitic boulders, 21 Aug 1993, W. R. Buck 23747, NY 3103644. DENMARK, Nyborg, 6 Dec. 1971, C-20156. FRANCE, Aveyron, Abbaye Notre-Dame de Bonnecombe, 29 Aug. 1959, G. Een, F258, S B30110. GERMANY, Bavaria, an Granit in Falkensteiner Park, an Bachufern in der Klamme, alt. 360-580, May 1903, I. Familler, S B281858; Berchtesgaden district, Schleching, on the ground in a wood, 6 Jun 1962, S. S. Hooper, E905518; BadenWürttemburg, Headwaters ofthe Elz River near Korallenhäus, NW from Schönwald, Naturpark, Südschwarzwald, alt. $927 \mathrm{~m}$, on rock in stream, 24 Apr. 2010, J. T. Wynns \& M. Lüth 3044, C 10632. HUNGARY, Comit Komárom, pr. Oroszlány, alt. 250 m, 8 Sep. 1937, A. Boros, E905534; Vertes Gebirge, in Erlenaäldern längs des Baches im Walde „Mocsárberek” genannt, neben dem Dorfe Oroszlány, alt. 200-250 m, 6 Dec. 1957, A. Boros, C-20084. IRAN, Mazandaran province, Nowshahr country, lower part of Veisar forest, FagusCarpinus forest type, 890 m, 2009, H. Zare, S B 171134. ITALY, Campello-Monti, prov. Novar. Pedemontii, in silva Valdo prope cataractam „die Dannai”, alt. 1250 m, 27 Aug. 1906, E. Levier, S B281867; Milano, Artaria, 16 Dec. 1896, S B281882. JAPAN, Hokkaido, Prov. Sôya, Isl. Rishiri, Mt. Rishiri, alt. 100-500 m, 8 Aug. 1954, H. Hasegawa, Z. Iwatsuki 15944, H3113590; 500 m, 8 Aug 1954, H. Hasegawa 15783, H3113589; Honsyu, Mt. Kiso-Ontake, on rocks in conifer forest, alt. 1250 m, 24 Aug 1953, N. Takaki, H3113623; Kagoghima Pref., Yakushima Island, alt. 420 m, on moist vertical face of boulder in full shade, 24 Sep. 1975, Z. Iwatsuki, G. L. Smith J-936, NY 3103681; Hiroshima Pref., Mt. Hibayama, alt. 1200 m, on rock, 11 Oct 1973, H. Ando, S B281902; Ibazi Prov., 27 Oct 1921, R. Jakenekin, H3113587. NORWAY, Rogaland, Vindafjord, Opsal, Vikedal, Edellauvskog, alt. $60 \mathrm{~m}$,

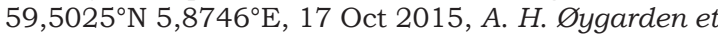
al., TRH B-12753. POLAND, Białystok nadl. Dojlidy oddz. 120, łęg, 26 May 1988, A. Sokołowski, BIL 8671; Nadleśnictwo Balinka, Puszcza Augustowska, łęg, 5 Sep. 1963, D. Goclawska, BIL 1437. RUSSIA, Caucas, Karachaevo-Cherkessian Republic, Teberda Natural Reserve, Shumka Creek, near waterfall, Abies + Fagus forest, on soil on steep slope, $43^{\circ} 24^{\prime} \mathrm{N}, 44^{\circ} 41^{\prime} \mathrm{E}$, alt. 1500 m, 16 Sep. 2005, M. Ignatov, E. Ignatova, S B 114218. SWEDEN, Södermanland, Ågestaberget, 27 Mar. 1959, G. Een, S B55593. SLOVAKIA, Ungern, Jul. 1913, J. A. Bäumkin, S B281872. SWITZERLAND, Kt. Zürich, Hirzel, W of Rüebgarten, tree base, 9 Mar. 1996, L. Hedenäs, S B281691. UNITED KINGDOM, Creinch, Loch, Lomond, on rock in oak wood, 24 May 1980, A. C. Crundwell, E905487; on rock in wood, 17 May 1953, A. C. Crundwell, E905494; Scotland, above the Sleat Peninsula, N. Ebudes, on sandy soil in the shade from a rock, alt. 104. 23 Aug. 1968, C. C. Townsend, E905483. 
Plagiothecium longisetum Lindb., Acta Soc. Sci. Fenn. 10: 232 (1875).

BELGIUM, Commune de Yvoir, aux confins de Dorinne, Durnal et Purnode, vallée du Bocq, dans un bois de pente á exposition sud, sur rochers, Apr 1979, J. L. DeSloover 30.246, NY 3103766. CHINA, Yunnan Province, Gong-Shan County, Nu Jiang (Salween River), $47^{\circ} 38.4^{\prime} \mathrm{N}, 30^{\circ} 29^{\prime} \mathrm{E}$, alt. $2950 \mathrm{~m}$, mixed hardwood-conifer forest of Acer, Abies and Larix, on damp shaded granitic rock wall, 4 Oct. 2002, J. R. Shovock, M. Wenzahang 23354, E844310. FRANCE, Südvogesen, Bachschlucht S La rosiere, ca. $15 \mathrm{~km}, \mathrm{~S}$ Remiremont, Granitgestein, alt. 520 m, 23 Sep 1981, Eggers \& Frahm, NY 3103761; Haute-Saine, Suedwestvogesen, Ruisseaux de Ballon E Haut le Rhan bei der Refuge Fray, kalkspatreicher Granit, alt. 700 m, 3 Oct. 1999, J.-P. Fram, C-20098. GERMANY, München, 19 Sep. 1919, D. Dittmer, S B281853; Tübingen, Württemberg, Sep. 1869, F. Hegelmaier, S B281857. IRAN, Mazandaran province, Nowshahr country, lower part of Veisar forest, alt. 840 m, 2009, H. Zare, S B 171133 ; Tooska chal, alt. 915 m, 2009, H. Zare, S B171128. JAPAN, Hokkaido, Hidaka, Samani-ch, alt. 50 m, 20 Sep. 1970, Kobayashi, Iwatsuki, S B281906; Shikoku, Mt. Ishizuchi, Ehime Pref., alt. 700 m, on decayed trunk, 1 Nov. 1971, H. Ando, H3113621. MADERIA, Boca da Encumeada, E part of Lamaceiros, Laurel forest, boulder in brook, alt. 900-1000 m, 9 Apr. 1990, L. Hedenäs, S B8858. POLAND, łódzkie voivodeship, Zimna Woda reserve, on stump in Ribeso nigri-Alnetum glutinosae forest, 15 Dec 2017, G. J. Wolski, LOD 14933; Dolnośląskie voivodeship, Łęgi Źródliskowe koło Przemkowa reserve, on the log in Tilio-Carpinetum forest, 13 Dec. 2017, G. J. Wolski, LOD 14926; Poznań, na E od Jez. Maltańskiego, lasy komunalne, oddzi. 39 m., na korzeniach olszy, 28 Sep. 2002, A. Rusińska, POZG 7630. RUSSIA, Caucas occidentalis, Lazarevskoie distr., in vicinitate pagi Golvinka, $3 \mathrm{~km}$ ab ostoi fluminis Shakhe, in faucibus rivuli, alt. 20-100 m, 25 Mar 1983, V. Vašák, NY 3103750; KarachaevoCherkessin Republic, Teberda Nature Reseve, near waterfall, Abies+Fagus forest, on soil on steep slope, $43^{\circ} 24^{\prime} \mathrm{N}, 41^{\circ} 44^{\prime} \mathrm{E}$, alt. $1500 \mathrm{~m}, 16$ Sep. 2005, M. Ignatov, E. Ignatova, H3226596. SPAIN, Cantabria, Celada Marlantes, monte Matznzas, 42 ${ }^{\circ} 55^{\prime} 53^{\prime \prime} \mathrm{N}, 04^{\circ} 05^{\prime} 56^{\prime} \mathrm{W}$, alt. $1250 \mathrm{~m}$, roca en hayedo, 22 Nov. 2008, M. J. Cano 4782, BM 1007993. UNITED KINGDOM, Day Bank, Scammels Browe, Sumey, 16 Jan. 1976, BM976716; Cambridgeshier, Madingley Wood, tre base, TL 40 59, Nov. 1948, P. J. Chamberlain 675 (S. 123), E350158; Hay Ley Dingl, Leigh, Woreal, 5 Apr. 2004, J. A. Paton \& R. Fisk 2821, E905435; South of West Horsle, Sumey, on bole of ash in wood, 27 Dec. 1955, E. C. Wallacee \& A. C. Crundwell, E905450; Wooded valley near Balcombe, East Sussex, 2 Apr. 1957, R. A. Boniface, BM 1103855.

\section{RESULTS}

\section{Sporophyte description of Plagiothecium nemorale and $P$. longisetum}

The reddish-brown seta is smooth and straight in both species. The capsule is inclined to horizontal and is usually cylindrical (Fig. 1). Even when dry, the capsule is smooth and usually dark brown, 2.6-3.5 × 1-1.2 mm. The exothecial cells are thin-walled, hexagonal to longhexagonal, 34-68 × 21-51 $\mu \mathrm{m}$. The operculum is usually straight, $0.8-1.8 \mathrm{~mm}$ in length, longconic to rostrate, and the annulus is composed of 2-3 rows of cells, 50-64 × 21-35 $\mu \mathrm{m}$. The double peristome is well developed (Fig. 1). The exostome teeth are lanceolate, narrowly triangular, and bright orange to yellowish, 400-600 $\times 80-119 \mu \mathrm{m}$. The outer surface of the exostome teeth in the lower part is striolate, and clearly papillose in the upper part. The exostome teeth themselves are trabeculate at the back, 10-26 $\mu \mathrm{m}$ (Figs 2-3). The endostome teeth are yellowish clearly segmented and form a triangular prism shape, 360-600 $\mu \mathrm{m}$. At the base, the segments are sparsely papillose, much more densely so in the upper part, and clearly and intensively papillose inside (Fig. 4). The cilia, $300 \mu \mathrm{m}$ in length, are clearly nodose with large swellings at cell boundaries, and clearly papillose along their entire length. The spores are spherical, 9-12 $\mu \mathrm{m}$ in diameter, and quite strongly papillose.

No explicit variation was observed for the shape, arrangement, length, or width of the capsule; the shape or dimensions of the exothecial cells, the dimensions or micromorphology of the endostome teeth, or the spores. However, in the group of studied specimens, some variability was noted in the length of the seta, and in the micromorphology of the surface of the exostome teeth. In addition, even the same trabecular areas can be differentially papillose, both quantitatively and qualitatively, with their ornamentation varying with regard to density (sparse or dense), diameter (thinner, thicker) and shape (straight, curved); sometimes even bifid papillae are present. The surface is heterogeneously papillose, varies according to the specimen being tested, which can be densely or rarely spiculose. It also depends on the position of the trabecula, 


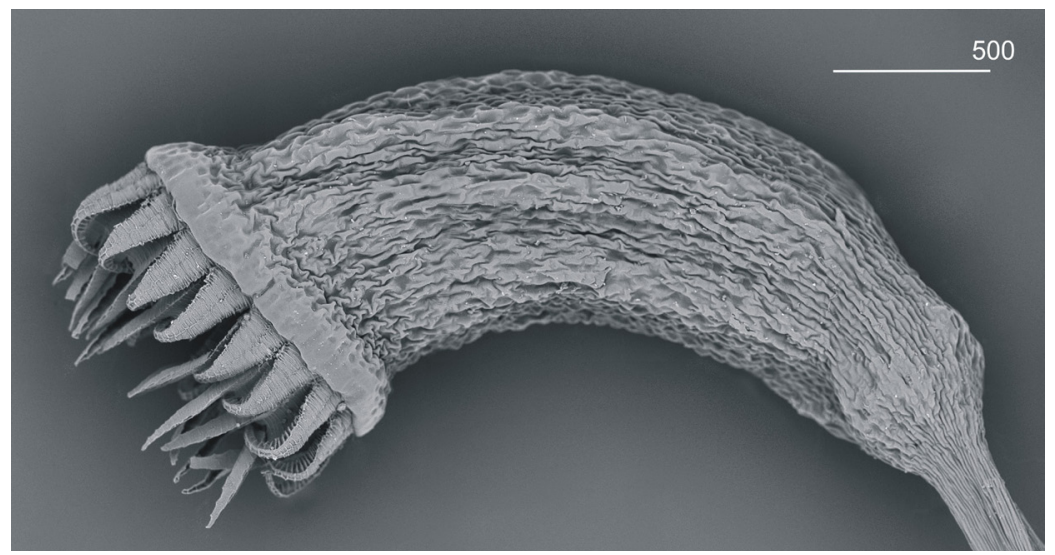

Fig. 1. The shape and arrangement of the capsule and double peristome of Plagiothecium nemorale (A. Sokolowski, BIL 8671); scale bar in $\mu \mathrm{m}$.
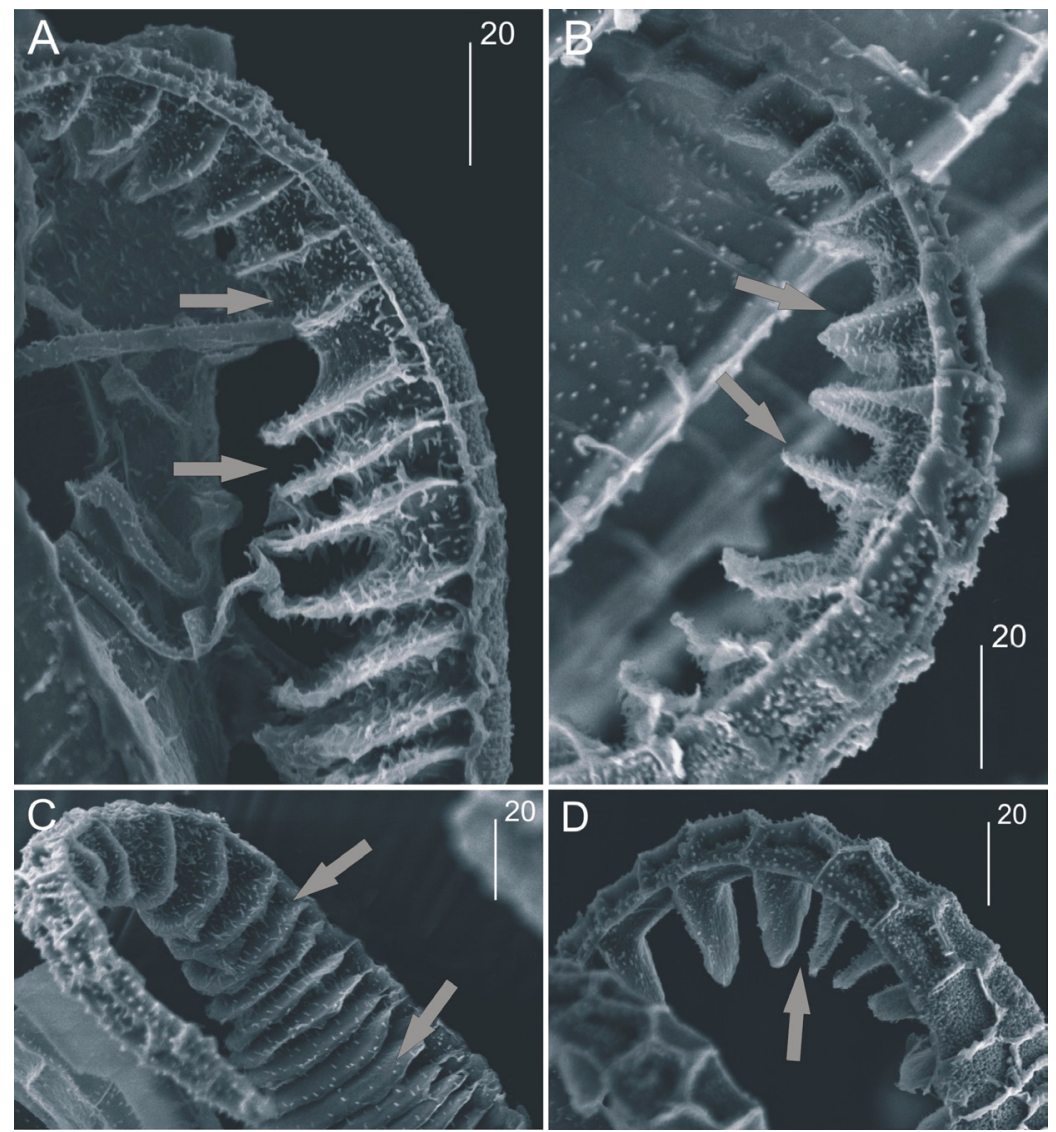

Fig. 2. Rarely spiculose trabeculae of the exostome teeth of Plagiothecium nemorale (A - H. Hasegawa, H3113589; B - Eggers \& Frahm, NY 3103761; C - A. C. Crundwell, E905487; D - A. H. Øygarden et al. TRH B-12753). The gray arrows indicate selected examples of places where the described feature is located; scale bars in $\mu \mathrm{m}$. 

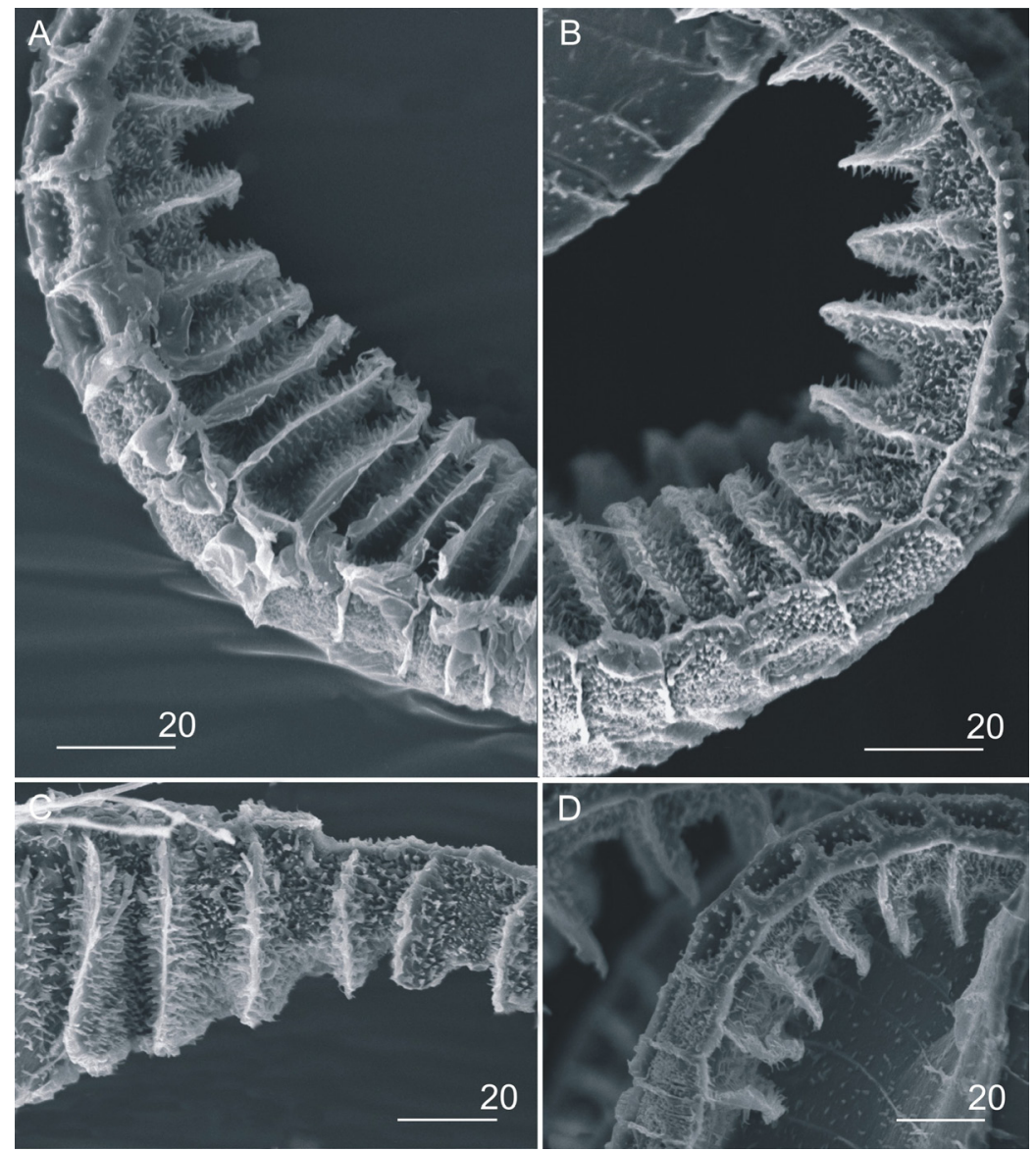

Fig. 3. Densely spiculose trabeculae of the exostome teeth of Plagiothecium longisetum (A - J.-P. Frahm, C-20098; B - R. A. Boniface, BM 1103855; C - J. A. Paton \& R. Fisk, 2821, E905435; D - H. Zare, S B 171128); scale bars in $\mu \mathrm{m}$.

with the lower positions much more weakly and loosely papillose than the higher locations (Figs 2-3).

The seta of Plagiothecium nemorale is short (3$3.5 \mathrm{~cm})$, the lower portion of the outer surface of the exostome teeth is charcterised by looselyarranged, moniliform cristae, while the upper side has conical papillae, and the inner surface is much more gently papillose (Figs $2,5,6$ ). In contrast, the seta of $P$. longisetum is markedly longer (i.e. up to $5.5 \mathrm{~cm}$ ). The lower portion of the outside of the exostome teeth of $P$. longisetum has tightly arranged, epapillose cristae, while the upper side has clearly flattened papillae, and their inner surface is much more strongly papillose (Figs. 3, 7, 8).

\section{DISCUSSION}

Many species of Plagiothecium have never been the object of SEM research. Although three studies have examined the micromorphology of species of Plagiothecium (Ireland, 1987; Ignatov et al., 1996; Ireland, 2001), the cited articles did not address the sporophytes of $P$. nemorale.

Our present findings confirm the presence of known qualitative and quantitative features of the sporophyte visible through the light microscope (Lindberg, 1872; Jedlička, 1948; Nyholm, 1965; Iwatsuki, 1970; Lewinsky, 1974; Noguchi, 1994; Smith, 2001). However, Noguchi (1994) gives much higher values for the length of the capsules $(4.5 \mathrm{~mm})$ than observed here. In addi- 

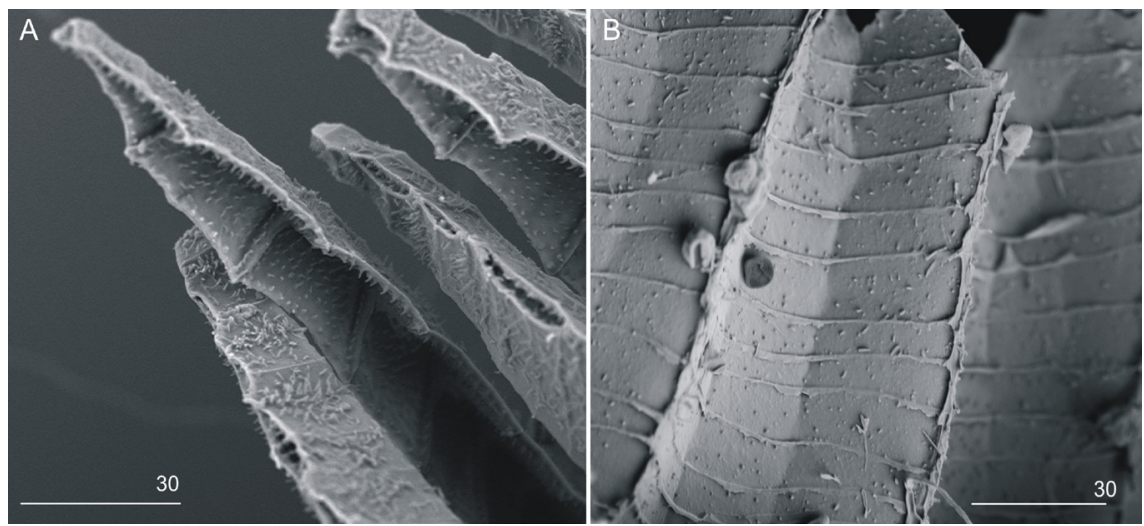

Fig. 4. The endostome of Plagiothecium nemorale: segmented and densely papillose in the upper part (A), and sparsely papillose in the lower part (B) (G. J. Wolski, LOD 14926); scale bars in $\mu \mathrm{m}$.
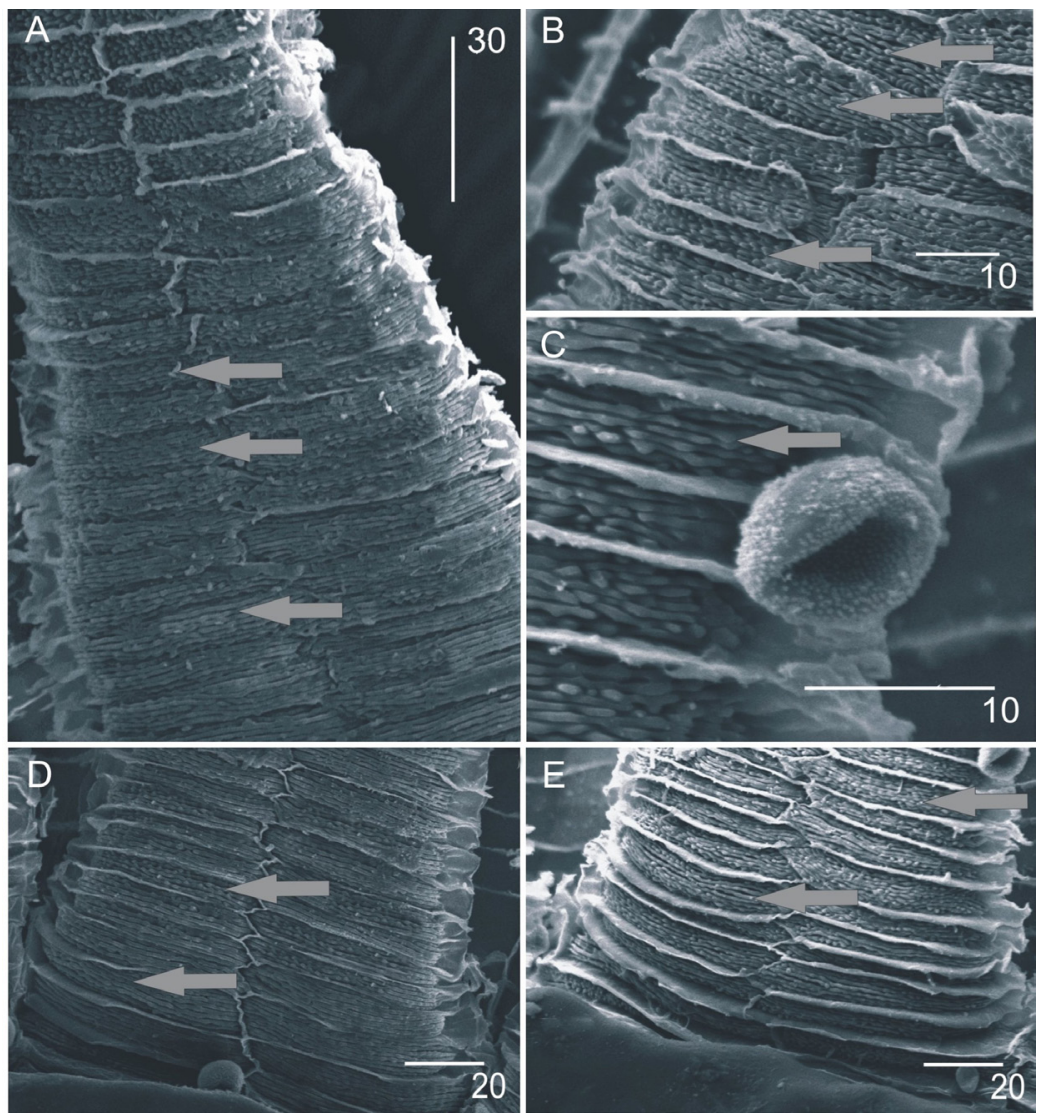

Fig. 5. The moniliform cristae of the bottom part of the outer surface of the exostome teeth of Plagiothecium nemorale (A - R. Jakenekin, H3113587; B, E - C. C. Townsend, E905483; C - A. Boros, E905534; D - W. R. Buck, 23747, NY 3103644). The gray arrows indicate selected examples of places where the described feature is located; scale bars in $\mu \mathrm{m}$. 

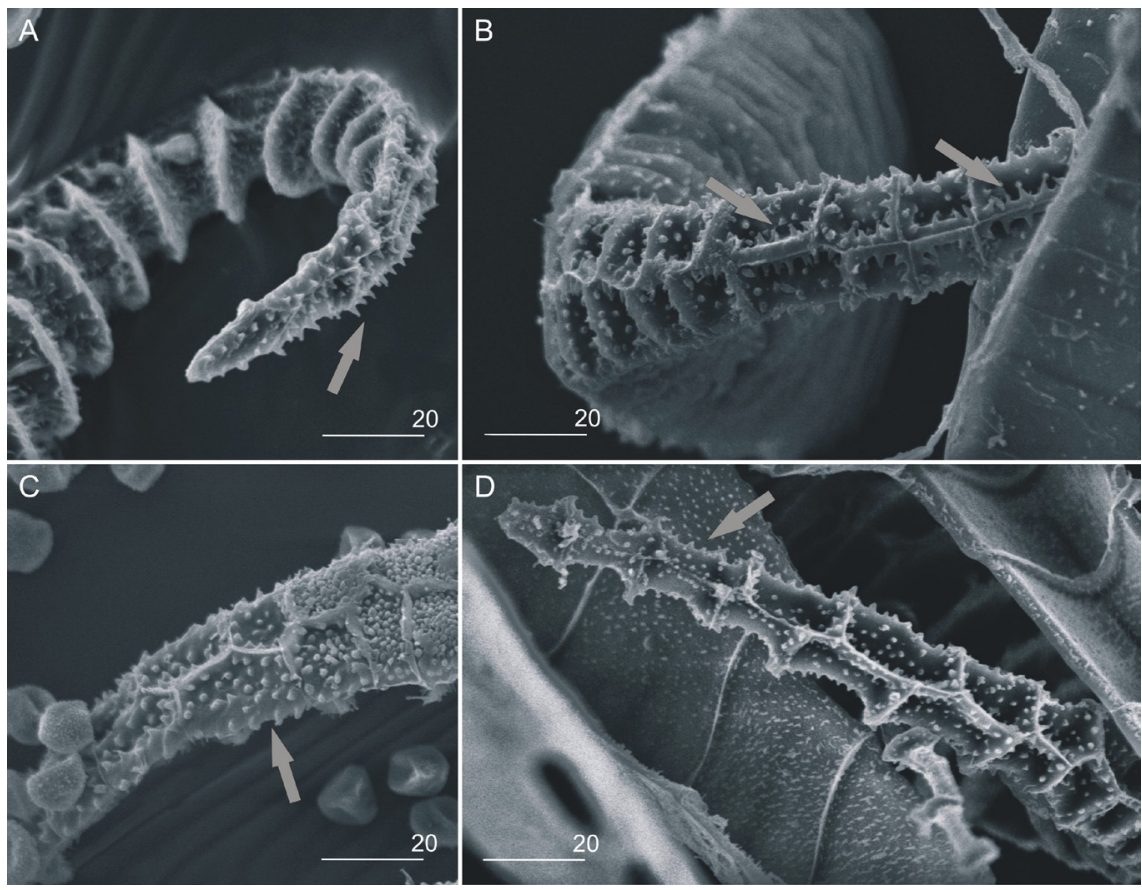

Fig. 6. Conical papillae of the top part of the outer surface of the exostome teeth of Plagiothecium nemorale (A - A. C. Crundwell, E905487; B - W. R. Buck 23747, NY 3103644; C - A. Boros, C-20084; D - A. H. Øygarden, et al. TRH B-12753). The gray arrows indicate selected examples of places where the described feature is located; scale bars in $\mu \mathrm{m}$.

tion, we found slightly wider capsules than those observed in previous studies (Jedlička, 1948; Noguchi, 1994). No specimens with a capsule width of only $0.9 \mathrm{~mm}$ were recorded (Noguchi, 1994), but slightly wider capsules (1.2 mm width) were observed. Furthermore, no spore diameters as high as 14 or $15 \mu \mathrm{m}$ (Iwatsuki, 1970; Lewinsky, 1974; Noguchi, 1994) were observed.

In sporophyte micromorphology $P$. nemorale and $P$. longisetum differ significantly from other species. The outer and inner surfaces of the exostome teeth of $P$. cavifolium, $P$. laetum and $P$. denticulatum are quite similar, with both surfaces having small, sparse papillae (Ignatov et al., 1996). The structure of the sporophyte has been associated with the taxonomic status of Plagiotheciaceae species (Ignatov et al., 1996; Ignatov et al., 1998). According to these authors, the deviating sporophyte features of $P$. latebricola and $P$. piliferum justify their exclusion from the genus Plagiothecium (Ignatov et al., 1996).
Our findings indicate that the structures of the exostome teeth of the tested samples are variable. The lower part of the outer surface of the exostome is epapillose or moniliform. In the examined specimens, noticeable quantitative and qualitative differences were observed regarding the upper part of the outer surface of the exostome, as well as the papillose trabeculae of the inner surface of the exostome teeth.

A combination of our present findings with those of previous studies of the gametophyte of $P$. nemorale and P. longisetum (Wolski, 2017, 2018; Wolski \& Nowicka-Krawczyk, 2020) suggest that the following characteristics are indicative of $P$. nemorale sensu stricto: symmetrical leaves, a denticulate leaf apex, hexagonal or narrowly hexagonal leaf cells not longer than $100 \mu \mathrm{m}$ in the central part of the leaf, a short seta, a sporophyte with loosely-arranged, moniliform cristae on the lower portion of the outer surface of the exostome teeth, the presence of conical papillae in the upper portion, as well as a gently papillose 

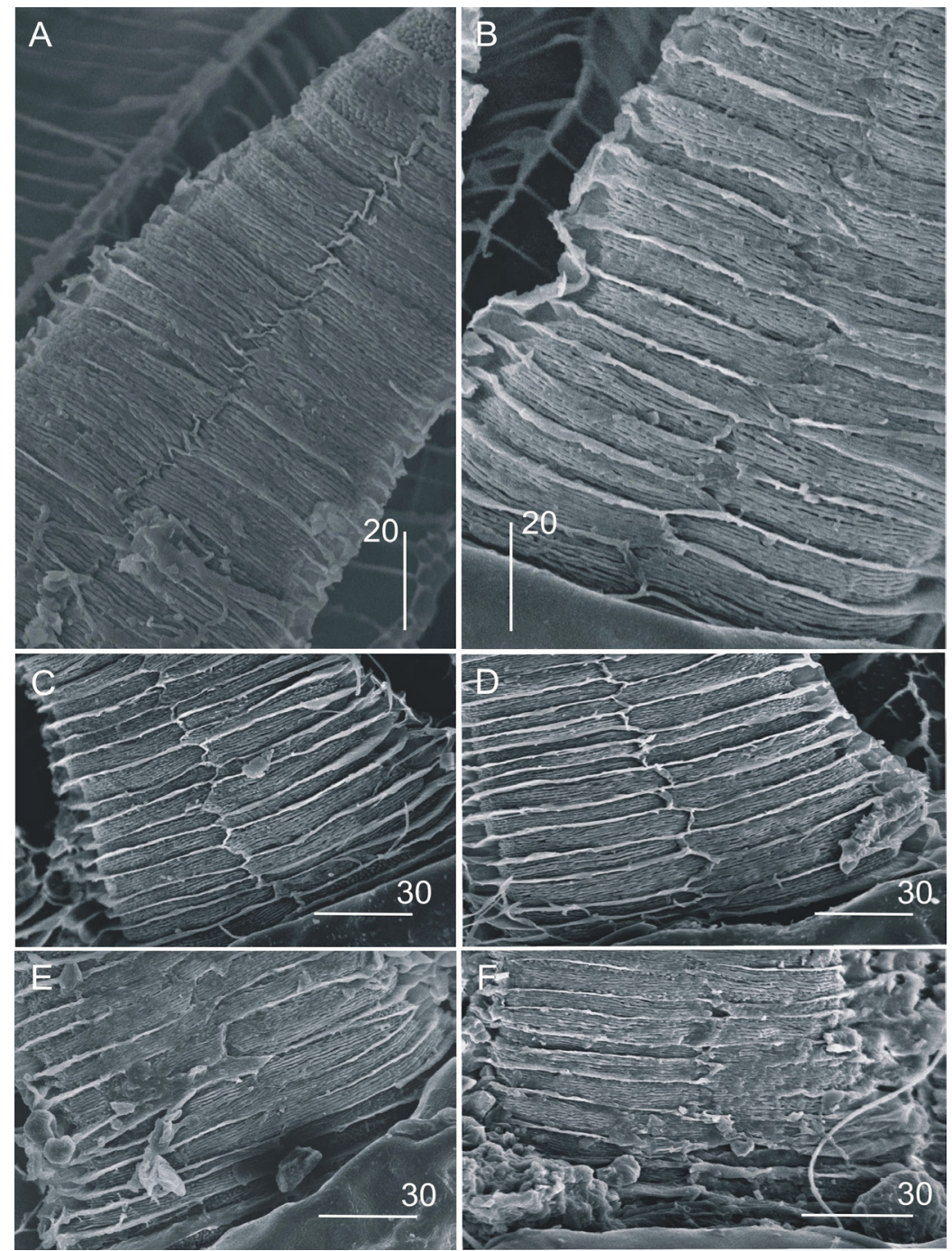

Fig. 7. The epapillose cristae of the bottom part of the outer surface of the exostome teeth of Plagiothecium longisetum (A - M. Ignatov, E. Ignatova, H3226596; B - Kobayashi, S B281906; C Eggers \& Frahm, NY 3103761; D - P. J. Chamberlain, 675, E350158; E - J. L. DeSloover, 30.246, NY 3103766; F - J. A. Paton \& R. Fisk, 2821, E905435); scale bars in $\mu \mathrm{m}$.

inner surface. In contrast, for P. longisetum, the gametophyte specimens are characterised by asymmetrical leaves, an entire leaf apex, the cells in the central part of the leaf elongated, hexagonal longer than $100 \mu \mathrm{m}$ but not exceeding $150 \mu \mathrm{m}$, a long seta, tightly arranged epapillose cristae on the bottom side of the outside of the exostome teeth with clearly flattened papillae on the upper side, and a much more strongly papillose inner surface. These associations between the respective states remain constant, despite the variation in other features observed for the studied species.

Our findings provide new information on the micromorphology of the exostome and endostome teeth in the studied species. These data not only confirm the hypothesis of Wolski (2017, 2018) that currently $P$. nemorale is too widely described, but also - as indicated by Wolski \& 

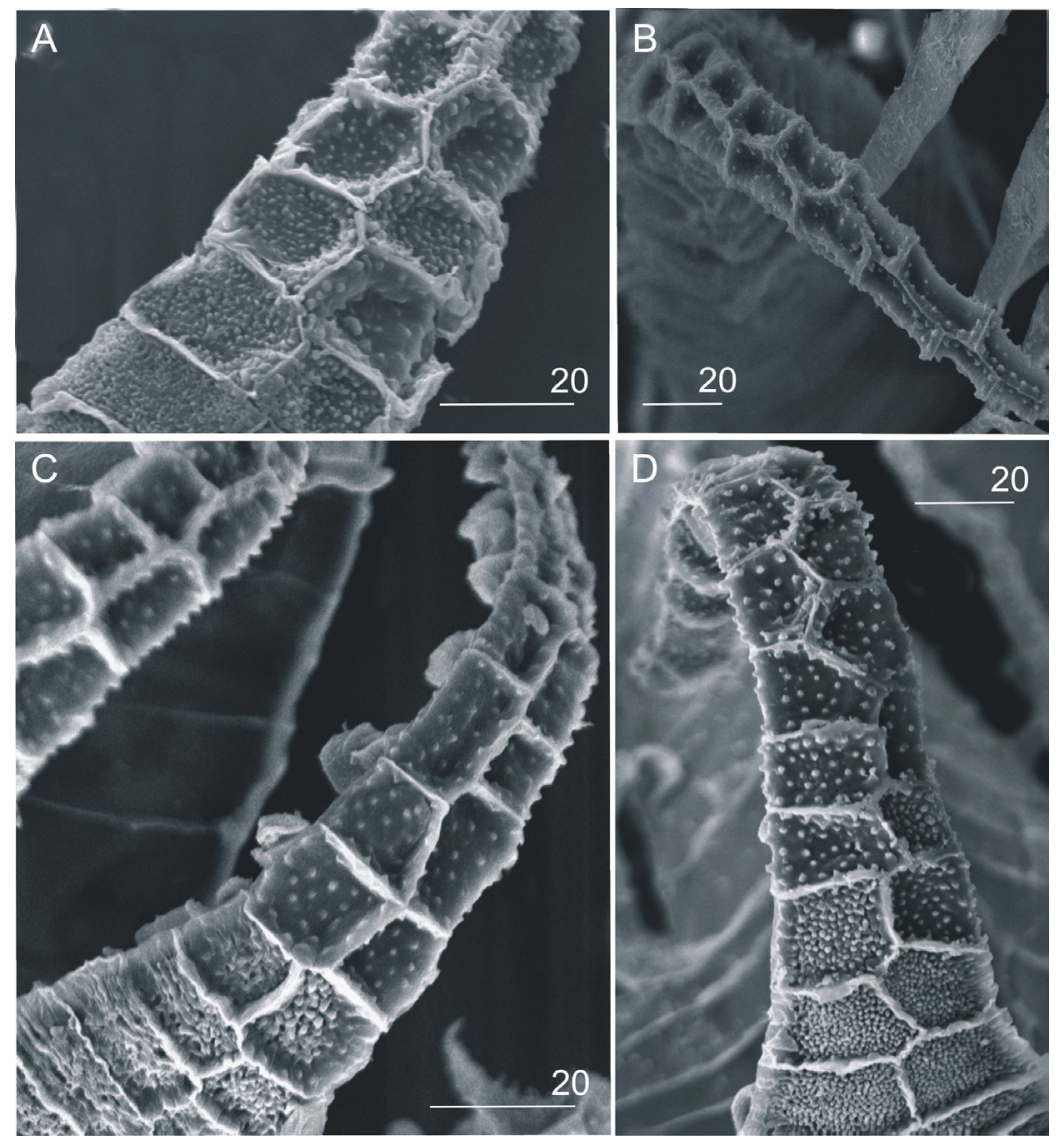

Fig. 8. Flattened papillae of the top part of the outer surface of the exostome teeth of Plagiothecium longisetum (A - J.-P. Frahm, C-20098; B - V. Vašák, NY 3103750; C - M. J. Cano, 4782, BM 1007993; D - E. C. Wallacee \& A. C. Crundwell, E905450); scale bars in $\mu \mathrm{m}$.

Nowicka-Krawczyk (2020) - that two distinct species can be distinguished within $P$. nemorale sensu lato. Furthermore, our study confirms that gametophyte variability is clearly reflected in the micromorphology of the sporophyte.

\section{ACKNOWLEDGMENTS}

The authors are grateful to the curators of the following herbaria: BIL, BM, C, E, H, LOD, NY, $\mathrm{POZG}, \mathrm{S}$ for the loan of specimens. We would also like to thank William R. Buck (Institute of Systematic Botany, New York Botanical Garden) for his helpful suggestions and language assistance, also, we would like to offer our thanks to the reviewers of the manuscript for their helpful comments, suggestions and text corrections.

\section{REFERENCES}

Buck, W. R. \& Ireland, R. R. 1989. Plagiotheciaceae. Flora Neotropica Monograph 50: 1-22.

Greene, S. W. 1957. The British species of the Plagiothecium denticulatum-P.silvaticum group. Trans Brit Bryol Soc. 3: 181-190. https://doi. org/10.1179/006813857804829623

Ignatov, M. S., Ando, H. \& Ignatova, E. 1996. Bryophyte flora of Altai Mountains. VII. Hypnaceae and related pleurocarps with bi- or ecostate leaves. Arctoa 6: 21-112. https://doi.org/10.15298/ arctoa.06.03

Ignatov, M. S., Robinson, H., Ignatova, E. A. 1998. Studies on the exostome of Brachytheciaceae (Musci). Arctoa 7: 153-188. https://doi. org/ 10.15298/arctoa.07.14

Ireland, R. R. 1969. A taxonomic revision of the genus Plagiothecium for North America, north of Mexico. National Mus. of Nat. Sci. 1: 1-118. 
Ireland, R. R. 1987. Scanning electron microscope study of the spores of the North American species of Plagiothecium (Musci). Mem. New York Bot. Gard. 45: 95-110.

Ireland, R. R. 2001. Buckiella, a new genus in the Hypnaceae (Musci). Novon 11: 55-62. https:// doi.org/10.2307/3393208

Iwatsuki, Z. 1970. A revision of Plagiothecium and its related genera from Japan and her adjacent areas, I. J. Hattori Bot. Lab. 33: 331-380.

Jedlička, J. 1948. Monographia specierum Europaerum gen. Plagiothecium s. s. Patis Specialis I. Summarium. Publications de la Faculté des Sciences de L'Univversité Masaryk 308: 1-45.

Jedlička, J. 1950. Monographia specierum europaerum gen. Plagiothecium s. s. Icones (Tabulae photographiae 1-7 et tabulae 1-32). Publications de la Faculté des Sciences de L'Univversité Masaryk 318: 1-7.

Lewinsky, J. 1974. The family Plagiotheciaceae in Denmark. Lindbergia 2: 185-217.

Lindberg, S. O. 1872. Contribution ad Floram Cryptogamam. Asie Boreali-Orientalis. I Musci Japonici. Acta Societatis Scientiarum Fennici 10: 221-280.

Mitten, W. 1859. Musci Indiae Orientalis; an enumeration of the Mosses of the East Indies. Journal of the Proceedings of the Linnean Society, Supplement to Botany 1: 1-174. https://doi.org/10.5962/ bhl.title. 156377

Noguchi, A. 1994. Illustrated moss flora of Japan. Part 5. J. Hattori Bot. Lab. Miyazaki-ken.

Nyholm, E. 1965. Illustrated Moss Flora of Fennoscandia. II. Musci. Fasc. 5. Lund. C.W.K. Gleerup.

Ochyra, R., Smith, R. L. \& Bednarek-Ochyra, H. 2008. Plagiotheciaceae. Illustrated Moss Flora of Antarctica. Published by Cambridge University Press, Cambridge 570-577.

Smith, A. J. E. 2001. The Moss Flora of Britain and Ireland. Cambridge, Cambridge University Press.

Wolski, G. J. 2017. Morphological and anatomical variability of Plagiothecium nemorale in Central Poland. Herzogia 30: 36-50. https://doi. org/10.13158/heia.30.1.2017.36

Wolski, G. J. 2018. Are Plagiothecium cavifolium, P. nemorale and $P$. succulentum indeed variable species? Pakistan J. Bot. 50: 1579-1589.

Wolski, G. J. \& Nowicka-Krawczyk, P. 2020. Resurrection of the Plagiothecium longisetum Lindb. and proposal of the new species $-P$. angusticellum. PLOS ONE 15(3): e0230237. https://doi. org/ 10.1371/journal.pone.0230237 